\title{
Book Review \\ "The Fluid Envelope of our Planet: How the Study of Ocean Currents Became a Science"
}

\author{
V. Schwach \\ Nordic Institute for Studies in Innovation, Research and Education (NIFU), \\ Wergelandsveien 7, 0167 Oslo, Norway \\ Correspondence to: V. Schwach (vera.schwach@nifu.no)
}

Eric L. Mills: The Fluid Envelope of our Planet: How the Study of Ocean Currents Became a Science, Toronto/London, University of Toronto Press, xiv+434 pp., ill., bibl., index, ISBN-13: 9780802096975 (cloth), €53.00, 2009.

\section{Introduction}

For more than three decades, Eric L. Mills has worked tirelessly to improve our understanding of history of oceanography. In doing this Mills has brought together his competence as an experienced oceanographer with the knowledge and methods of history of science, and he has combined his two fields of expertise with bravura. The topic in his recent book The Fluid Envelope of our Planet: How the Study of Ocean Currents Became a Science is the rise of dynamical oceanography. In this study, as in the previous works, Mills explores the many intellectual, professional, economic and national issues that shaped the formation of oceanography as a physical science discipline. He investigates how scientists came to understand fluid motions in the ocean as physical phenomena subject to mathematical analysis. In doing this Mills examines the development of hypothesis and theories on horizontal differences in temperature and salinity, today known as thermohaline circulation: the deep, slow movements of ocean waters produced by differences in density of the water. The density differences, in turn, are generated by variations of temperature and salinity.

\section{Time, topic and sources}

Historians study changes and continuance over time; the establishment of a chronology enables the examinations of changes. Mills' history starts with an overview of ideas about the ocean prior to the nineteenth century, but the main period covered is 1860-1960. Mills argues that a formative period of dynamic oceanography began with a discussion of the nature of ocean circulation; the research was intensified around 1900 and concluded with a successful theoretical physical model of the circulation reaching deep down in the ocean, often referred to as the deep or abyssal circulation. In building up a broad understanding of how ocean currents became subject to mathematical analysis, Mills analyzes the development of oceanographic research programs in succession of Scandinavia first, and then Canada, Germany, France, the USA, and at last back to Mills' homeland Canada.

The book draws on a wealth of archival files and printed sources, all carefully worked up. During the work Mills traveled to many countries, and has built the text on documentation found in archives in Germany, Norway, Monaco, United Kingdom, the USA and in Canada. Notes and references fill more than one fourth of the book's 434 pages. The book is carefully illustrated.

\section{Shaping oceanography}

The formation of oceanography was attached to what may look as unconnected factors. From the 1890 s to 1940 , civilian economic interests were of importance to gain insight into the ocean currents. Mills shows how the worries of the decline of the commercial sea fishery and the scientific fishery investigations contributed significantly to the knowledge production in physical oceanography. Later on, in the Second World War the use of submarines (and subsequently the emergence of the Cold War) became the backdrop for a substantial growth of physical oceanography, linked to military patronage, especially in the USA. The implications of a very 
different political situation and naval patronage for physical oceanography are somewhat vague in Mills' book.

The author addresses the importance of the research done by key contributors to the discipline, including among others William Carpenter, James Croll, Vilhelm Bjerknes, Bjørn Helland-Hansen, Johan Sandström, Johan Hjort, Harald Ulrik Sverdrup, Alfred Merz, Georg Wüst, George McEwen, Edward H. Smith, John Tully and Harry Hachey. The oceanographers are viewed as gifted scientific entrepreneurs and historical actors in a disciplinary and institutional setting, and not as unique geniuses detached from any cultural and institutional context.

The author pays careful attention to the various national styles in oceanography; but still the account is truly an international one, throughout its comparative approaches, and the awareness of the importance of international scientific communities, before 1940 and in particular The International Council for the Exploration of the Sea (ICES). Mills gives weight to the transition of theories, measurement standards, instruments and scientists crossing the Atlantic to introduce their research methods and theories to peers; two examples of this kind of scientific transition being the Canadian Fisheries Expedition of 1915 (pp. 111-136) and the appointment of H. U. Sverdrup as the Scripps director in 1936 (pp. 192231).

Mills narrates complex theoretical challenges with ease and focuses on major conceptual shifts as they materialized in articles, reports and books. The theory of dynamical oceanography was published as The Norwegian Sea: Its physical oceanography based upon the Norwegian researches 1900-1904, written by Bjørn Helland-Hansen and Fridtjof Nansen and printed in the Report on the Norwegian Fishery and Marine Investigations (1909). An epoch-making book that summed up the hitherto done research, and spurred new research approaches and practices was The Oceans: Their Physics, Chemistry, and General Biology (1942), by H. U. Sverdrup, M. W. Johnsen and R. W. Flemming. It was used in oceanographic courses for generations for students of physical oceanography.

Mills is confident in explaining scientific disagreements; this goes for the skepticism the Scandinavian mathematical approach to the ocean currents was met with at the Scripps Institution of Oceanography, La Jolla, USA. At Scripps in the 1920s and early 1930s, its leading oceanographer, George McEwen, was suspicious of mathematical oceanography, and saw it more as a pragmatic and convenient way of conducting research than as a paradigmatic shift in the theoretical understanding of the fluid motions in the ocean.

\section{France - an outsider}

A chapter of Mills' book is dedicated to investigating why France, perhaps unexpectedly, made few contributions to international physical oceanography until the 1960s (pp. 162-
191). This lack of involvement is a paradox given the country's formidable system of teaching, renowned universities and advanced marine stations. In addition French oceanography was linked to Monaco - a hotbed of oceanographic studies, owing to the abundant patronage of Prince Albert I of Monaco. Mill's main argument is the influence of France's dominant oceanographer in the early twentieth century, Julien Thoulet. Mills explains that Thoulet was convinced that complex mathematical modeling and interpretations of the ocean conditions was an impossible task. The French oceanographer rejected not only the mathematical approach but also the instruments, the standards for sampling and theory of dynamical oceanography, which had origins in Scandinavian research and was accepted in the ICES community. The French example underlines what should be a guiding point in all historical writing: no developments are deterministic processes; they are decided and carried out by handling historical actors.

\section{Conclusions}

My critical comments are very few and foremost driven by a desire to learn more about the Cold War period, when oceanographic courses and research flourished and were linked to national security concerns. I also wish for an additional study of evidently important countries not covered in the book, like the Soviet Union (Russia before 1917) and Japan. In its historical analysis of the rise of dynamical oceanography - mathematical approaches to ocean currents - Mills' The Fluid Envelope of our Planet is an outstanding example of what history of science is about: a narrative analysis of science done in the past, so that we do not have to content ourselves with a compilation of documents found in archival files, quotes and a collection of statements from the past.

Mills' book demonstrates convincingly the influential changes in the science of physical oceanography, and how the shifts depended upon the occurrence of events of time, place, professional and personal interaction, all possible, but not always likely or even intended. With The Fluid Envelope of our Planet, Mills has given considerable insight into how researchers came to regard fluid motions in the oceans as physical phenomena subject to mathematical analysis, both in an internal scientific context and in a broader, political and cultural setting. Narrating history means dealing with a specific research question and concurrently unfolding new research questions and stories to be constructed and argued over. Mills' outstandingly crafted The Fluid Envelope of our Planet already has, or will soon, gain status as a classic in the history of oceanography, and it forms a firm basis for coming studies. 